\title{
Assessment of pathogenic bacteria in water and sediment from a water reservoir under tropical conditions (Lake Ma Vallée), Kinshasa Democratic Republic of Congo
}

\author{
Paola M. Mwanamoki • Naresh Devarajan • Florian Thevenon • \\ Emmanuel K. Atibu • Joseph B. Tshibanda • Patience Ngelinkoto • Pius T. Mpiana • \\ Kandasamy Prabakar • Josué I. Mubedi • Christophe G. Kabele • Walter Wildi • \\ John Poté
}

Received: 18 November 2013 / Accepted: 18 June 2014 /Published online: 1 July 2014

(C) Springer International Publishing Switzerland 2014

\begin{abstract}
This study was conducted to assess potential human health risks presented by pathogenic bacteria in a protected multi-use lake-reservoir (Lake Ma Vallée) located in west of Kinshasa, Democratic Republic of Congo (DRC). Water and surface sediments from several points of the Lake were collected during summer. Microbial analysis was performed for Escherichia coli,
\end{abstract}

P. M. Mwanamoki • C. G. Kabele

Section Nutrition diététique, Institut Supérieur des Techniques Médicales/Kinshasa,

B.P. 774, Kinshasa XI, Democratic Republic of Congo

N. Devarajan $\cdot$ F. Thevenon $\cdot$ W. Wildi $\cdot$ J. Poté $(\bowtie)$

Faculty of science, Forel Institute and Institute of

Environmental Sciences, University of Geneva,

CP 416, 1290 Versoix, Switzerland

e-mail: john.pote@unige.ch

N. Devarajan $\cdot$ K. Prabakar

Postgraduate and Research Department of Zoology, Jamal

Mohamed College,

Tiruchirappalli 620020 Tamil Nadu, India

E. K. Atibu • J. B. Tshibanda • P. T. Mpiana · J. Poté Department of Chemistry, Faculty of Science, University of Kinshasa (UNIKIN),

B.P. 190, Kinshasa XI, Democratic Republic of Congo

P. Ngelinkoto · J. I. Mubedi · J. Poté

Université Pédagogique Nationale (UPN),

Croisement Route de Matadi et Avenue de la Libération.

Quartier Binza/UPN, B.P. 8815, Kinshasa, Democratic

Republic of Congo
Enterococcus (ENT), Pseudomonas species and heterotrophic plate counts. PCR amplification was performed for the confirmation of E. coli, ENT, Pseudomonas spp. and Pseudomonas aeruginosa isolated from samples. The results reveal low concentration of bacteria in water column of the lake, the bacterial quantification results observed in this study for the water column were below the recommended limits, according to WHO and the European Directive 2006/7/CE, for bathing water. However, high concentration of bacteria was observed in the sediment samples; the values of $2.65 \times 10^{3}, 6.35 \times 10^{3}, 3.27 \times 10^{3}$ and $3.60 \times 10^{8}$ CFU $\mathrm{g}^{-1}$ of dry sediment for E. coli, ENT, Pseudomonas spp. and heterotrophic plate counts, respectively. The results of this study indicate that sediments of the Lake Ma Vallée can constitute a reservoir of pathogenic microorganisms which can persist in the lake. Possible resuspension of faecal indicator bacteria and pathogens would affect water quality and may increase health risks to the population during recreational activities. Our results indicate that the microbial sediment analysis provides complementary and important information for assessing sanitary quality of surface water under tropical conditions.

Keywords Lake Ma Vallée · Microbial contamination · Faecal indicator bacteria $\cdot$ Pseudomonas . Human health risk - Democratic Republic of Congo 


\section{Introduction}

The contamination of drinking and recreational water resources by pathogenic organisms and micropollutants is a major problem in many parts of the world. In developing countries, the diarrheal diseases, mainly due to the consumption of microbiologically contaminated drinking water, cause about one billion illnesses and 2.2 million deaths per year (Montgomery and Elimelech 2007). Although most infections occur in developing countries, waterborne diseases are a worldwide problem that also concern industrialized societies where highly populated centres draw their supply of drinking water (Thevenon et al. 2013; Poté et al. 2009a). Faecal pollution can originate from a variety of human and non-human sources, but faecal indicator bacteria (FIB) contamination from human faecal material is generally considered to be a greater risk to human health as it is more likely to contain human enteric pathogens (Scott et al. 2003; Haller et al. 2009a).

FIB reside in the gastrointestinal tracts of humans and animals, and are commonly used to assess the microbiological safety of drinking and recreational waters. Although indicator bacteria do not necessarily cause illness, their presence indicates that the water has been contaminated by faecal material and indicates therefore the potential presence of pathogens (An et al. 2002; Noble et al. 2003). The surface recreation water generally contains indigenous microorganisms, pathogenic and non-pathogenic microbes. The choice of bacterial indicators is thus very important for the management of aquatic environmental quality. The US Environmental Protection Agency and the European Union recommend the use of Escherichia coli, a subset of the faecal coliform group, and members of the genus Enterococcus (ENT), to assess the hygienic safety of recreational waters (USEPA 2000; WHO 2004; EU 2006). Both, heterotrophic plate count (HPC) and Pseudomonas aeruginosa, an opportunistic pathogen responsible for numerous infections especially for the persons with weakened immune systems, are often used as additional water quality indicators (Poté et al. 2009a; Varga 2001).

Exposure to bathing waters with high concentrations of E. coli, ENT and P. aeruginosa are documented in epidemiological studies as being associated with an increased risk of contracting gastrointestinal and respiratory illnesses. It has been demonstrated that during recreational activities, exposure to high concentrations of the faecal bacteria in recreational waters may increase the risk of illness and disease, including gastrointestinal, respiratory illnesses and skin, ear and eye infections
(Crabelli 1983; Kay et al. 1994; Prüss 1998; Haile et al. 1999).

Sediments may contain (100 to $1,000 \times$ ) more FIB as the overlying water (Davies et al. 1995; Poté et al. 2010). Recent studies demonstrated that the evaluation of FIB in sediments may be a more stable index of overall or long-term water quality than in the overlying water (Laliberte and Grimes 1982; Ferguson et al. 2005; Haller et al. 2009b). Thus, the monitoring of FIB levels in the water column, accumulation and resuspension of FIB from sediments should also be taken into account. Depending on sediment characteristics, coastal sediments can act as a reservoir of FIB. Analysis of water quality alone may underestimate the risk of exposure to potentially pathogenic microbes in recreational waters (Craig et al. 2002; Poté et al. 2009b). Some studies demonstrated that sediments can constitute as an important reservoir for FIB in freshwater environments (LaLiberte and Grimes 1982; Burton et al. 1987; An et al. 2002; Haller et al. 2009a).

Lake Ma Vallée is a scenic African Lake surrounded by the equatorial forest. The lake is well protected and known as a place of leisure, sports and relaxation by different classes of population. A small dam, a creek mouth and water form an intimate lake and the surrounding forest is still primitive. The lake is considered as a reservoir for various activities including swimming, canoe, fishing and rowing boats. To our knowledge, no regular water quality monitoring and research programmes have been conducted to assess the microbial and physico-chemical qualities of the lake. Thus, the present research was carried out to assess the microbial quality of the lake. The assessment is based on the quantification and characterization of Pseudomonas spp., FIB including E. coli, ENT and HPC in both, water column and sediments from the lake. The spatial microbial distribution was performed by sampling sediments from eight sites distributed on either sides of the lake. The influence of sediment characteristics including sediment grain size and organic matter content on FIB accumulation and persistence was also examined.

\section{Materials and methods}

Study site and sampling procedure

Lake Ma Vallée is located about $30 \mathrm{~km}$ west of the city of Kinshasa with a surface area of $2.44 \mathrm{~km}^{2}$ (6 km long). 
Each month, approximately 640 peoples visit the lake for different recreational activities. Sampling was done during low flow of water with stratified lake conditions on June 2013. Canoes were used to collect core sediment samples and water samples from the lake. Water samples $(250 \mathrm{~mL})$ were duplicated from three sites (EM, stream inlet; MM, middle of lake; and SM, stream outlet) and pooled in $1 \mathrm{~L}$ sterile bottles. Surface sediment $(n=8)$ was sampled from both the banks of the lake: on the right bank side noticed 1D-4D and the left side noticed $1 \mathrm{G}-4 \mathrm{G}$ (Fig. 1). The samples were placed in sterile containers and stored in an icebox at $4{ }^{\circ} \mathrm{C}$ and transported to laboratory. At the point of sampling, physico-chemical characteristics of water, such $\mathrm{pH}$, electrical conductivity and temperature were measured using a Multi 350i (WTW, Germany).

\section{Sediment characterization}

The grain size distribution was measured using a particle size analyzer Coulter ${ }^{\circledR}$ LS-100 (Beckman Coulter, Fullerton, CA, USA), following ultrasonic dispersal in deionized water (Loizeau et al. 1994). The proportions of three major size classes (clays $<2 \mu \mathrm{m}$; silts $2-63 \mu \mathrm{m}$; and sand $>63 \mu \mathrm{m}$ ) were determined from size distributions, as well as the median grain size. Sediment total water content was measured by drying the samples at $60{ }^{\circ} \mathrm{C}$ for overnight and the weight loss was taken for the percentage of water content. Sediment total organic matter content and $\mathrm{CaCO}_{3}$ was estimated by loss on ignition for $1 \mathrm{~h}$ in Salvis oven (Salvis $A G$, Emmenbrücke, Luzern, Switzerland).

Bacteria analysis by selective culture method

The FIB (E. coli and ENT) were quantified in the water and sediment samples using the method previously described by Balkwill and Ghiorse (1985) and modified by Haller et al. (2009a). Bacterial analysis in the water and sediment supernatant was estimated according to the international standard methods for water quality determination using the membrane filtration method (APHA 2005; Haller et al. 2009a, b). Briefly, the sediments were resuspended by adding $100 \mathrm{~g}$ of fresh sediment to $500 \mathrm{~mL}$ of $0.2 \% \mathrm{Na}_{6}\left(\mathrm{PO}_{3}\right)_{6}$ in $1 \mathrm{~L}$ sterile plastic bottles and mixed for $30 \mathrm{~min}$ using the agitator rotary printing-press Watson-Marlow 601 controller (Skan, Switzerland). The mixture was then centrifuged at 4,000 rpm for $15 \mathrm{~min}$ at $15{ }^{\circ} \mathrm{C}$. For each sample, triplicates of serially diluted sediment supernatant $(100 \mathrm{~mL})$ was passed through a $0.45-\mu \mathrm{m}$ filter $(47 \mathrm{~mm}$ diameter, Millipore, Bedford, USA) and placed on different selective culture media (Biolife Italiana) supplemented with the anti-fungal compound Nystatin (100 $\mu \mathrm{g} \mathrm{mL}^{-1}$ final concentration), using the following incubation conditions: E. coli-Tryptone Soy Agar (TSA) medium, incubated at $37^{\circ} \mathrm{C}$ for $4 \mathrm{~h}$ and transferred to Tryptone Bile X-Gluc Agar (TBX) medium at $44{ }^{\circ} \mathrm{C}$ for $24 \mathrm{~h}$; ENT-Slanetz Bartley Agar (SBA) medium, incubated at $44{ }^{\circ} \mathrm{C}$ for $48 \mathrm{~h}$ and transferred into Bile Aesculin Agar (BAA) medium at $44^{\circ} \mathrm{C}$ for $4 \mathrm{~h}$; Pseudomonas spp.-Pseudomonas selective Agar incubated for $24 \mathrm{~h}$ at $37^{\circ} \mathrm{C}$. The HPC were determined using spread plate method on TSA after 48-72 $\mathrm{h}$ incubation at $28{ }^{\circ} \mathrm{C}$ (Poté et al. 2009b). The results are expressed as colony forming units per $100 \mathrm{~mL}$ of water (CFU $100 \mathrm{~mL}^{-1}$ ) or $100 \mathrm{~g}$ of dry sediments (CFU $100 \mathrm{~g}^{-1}$ ). The reproducibility of the whole experimental procedure was tested by means of triplicates on selected sediment samples.

\section{PCR for confirmation of E. coli, ENT, Pseudomonas spp. and P. aeruginosa}

General confirmation of E. coli, ENT, Pseudomonas spp. and $P$. aeruginosa were performed by PCR assay using specific primers and operational conditions as summarized in Table 5. PCR assay were performed on genomic DNA extracted from the isolated colonies grown on selective media. Genomic DNA was extracted using $5 \%$ Chelex ${ }^{\circledR} 100$ and proteinase $\mathrm{K}$ as described by Walsh et al. (1991) and Yang et al. (2008). Briefly, $5 \mathrm{~g}$ of Chelex resin (Bio-Rad) and $0.02 \mathrm{~g}$ of Proteinase K were dissolved in $100 \mathrm{~mL}$ of molecular grade water, mixed thoroughly and refrigerated. Two hundred microlitres of this solution was dispensed to sterile $1.5 \mathrm{~mL}$ tubes and a loopful $(10 \mu \mathrm{L})$ of bacterial colonies grown on selective media were added to the aliquot and incubated at $56^{\circ} \mathrm{C}$ for $4-6 \mathrm{~h}$ or overnight, and vortexed briefly. The tubes were then boiled at $95{ }^{\circ} \mathrm{C}$ for $8_{-}^{-}$ $10 \mathrm{~min}$ and cooled in a freezer for 15-20 min, centrifuged at 13,000 rpm and the supernatant was transferred to fresh tubes. The extracted DNA was quantified spectrophotometrically $\left(\mathrm{OD}_{260}\right)$ and the quality was assessed on selected samples by electrophoresis on $1 \%$ agarose gel stained with $1 \times$ SYBR safe DNA gel stain (Invitrogen) in $1 \times$ TAE buffer. DNA was stored at $-20{ }^{\circ} \mathrm{C}$ until used. 


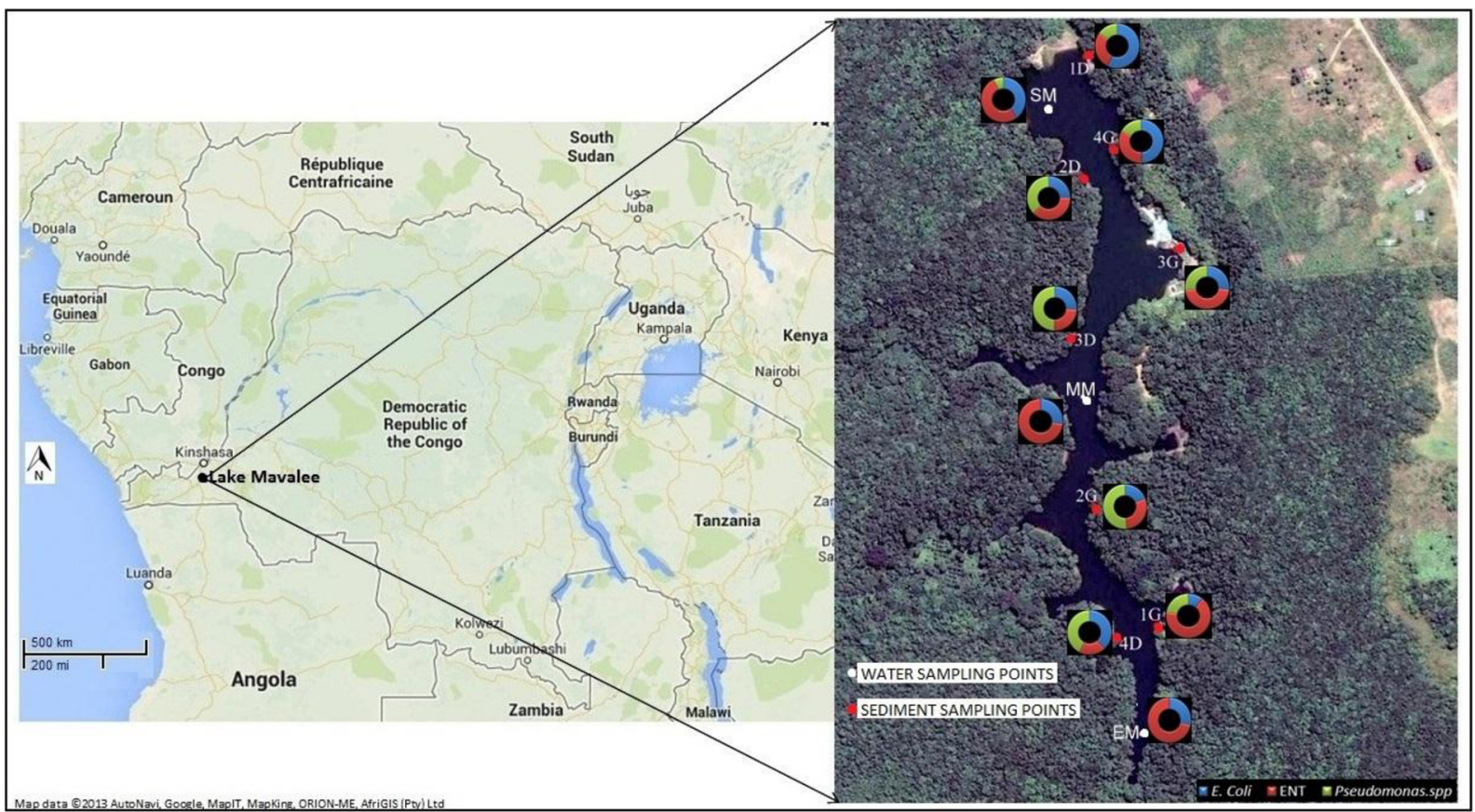

Fig. 1 Geographical location of Lake Ma Vallée and the point of sample collection indicating the concentration of E. coli, ENT and Pseudomonas spp. ratio

PCR was performed on Biometra thermocycler (BIOLABO) in a $20-\mu \mathrm{L}$ reaction mixture containing $1 \mu \mathrm{L}$ of processed DNA template, $0.4 \mu \mathrm{mol}$ of each primer (Invitrogen), $200 \mu \mathrm{mol}$ of dNTP mix (Sigma Aldrich), 1 unit of RED Taq DNA polymerase (Sigma Aldrich) and $1 \times$ PCR buffer (containing $1.1 \mathrm{mM}$ of $\mathrm{MgCl}_{2}$ ). Samples were subjected to the following thermal cycling conditions: initial denaturation $94{ }^{\circ} \mathrm{C}$ for 5 min, following 35 cycles at $94{ }^{\circ} \mathrm{C}$ for $30 \mathrm{~s}$, appropriate annealing temperature (Table 5) for $1 \mathrm{~min}, 72{ }^{\circ} \mathrm{C}$ for $1 \mathrm{~min}$ and final 10 -min extension at $72{ }^{\circ} \mathrm{C}$. PCR products were visualized on $1.3 \%$ agarose gel stained with $1 \times$ SYBR safe DNA gel stain in $1 \times$ TAE buffer.

The experiment was conducted in triplicate with each set of conditions. Negative (without DNA) and positive (genomic DNA extracted from BD Microtrol ${ }^{\mathrm{TM}}$ E. coli ATCC25922, Enterococcus faecalis ATCC 29212 and $P$. aeruginosa ATCC 27853) were used for each set of PCR assay.

Data analysis

For all analyses, the triplicate measurements have been performed on selected sediment samples. Statistical treatment of data (Spearman rank order correlation) has been realized using SigmaStat11.0 (Systat Software, Inc., USA).

\section{Results and discussion}

Physico-chemical analysis of water and sediment

The physico-chemical parameters of water and sediments are given in Tables 1 and 2. The $\mathrm{pH}$ value 5.9 of lake water was observed in all parts of the lake. The lake temperature ranged between 23.7 and $25.3^{\circ} \mathrm{C}$. The water electrical conductivity and dissolved oxygen in water are very low, with maximum value of $12.8 \mu \mathrm{S} \mathrm{cm}^{-1}$ and $1 \%$, respectively. The samples were collected during summer period and the flow of the lake was almost stabilized. There are many aspects which can explain the low values of $\mathrm{pH}$, conductivities and dissolved oxygen in the water, including the presence of equatorial forest surrounding the lake (organic matter input, low mineralization under tropical condition), and the presence of silicate and aluminium compounds in the area. Additionally, the probable low contribution of ground water into the lake and the probable high primary production can explain the low value of dissolved oxygen. 
Sediment particle size and organic matter content in sampled sediments are shown in Table 2. The sediments present high organic matter content with the values range from 10.3 to $16.6 \%$. The maximum value was observed in the site $2 \mathrm{D}(16.6 \%)$. The sediments were composed majorly with silts, the values ranged from 30.7 to $69.6 \%$. Except for the sites 1D (54.4\% of sand) and 4D (43.9\% of sand), all sampled sites are especially constituted with silts and clay. The lowest concentration of sand was observed in the sites $1 \mathrm{G}(0.7 \%)$ and $3 \mathrm{G}$ $(0.0 \%)$. The high sediment median grain size value was observed in the site $1 \mathrm{D}(105.8 \mu \mathrm{m})$ and lowest $(4.30 \mu \mathrm{m})$ for the site $3 \mathrm{G}$. $\mathrm{CaCO}_{3}$ values were very less for all sediment samples and do not exceed $2 \%$ with all the studied samples.

The particle size distribution is found to be influenced by the hydrodynamic aspects of the lake, probably by the dynamic of stream input action and wave that can create a high energy. Coarser sediments were located close to the shores, especially in the stream outlet (site 1D), with median value of $105 \mu \mathrm{m}$ and values of 30.6, 14.8 and $54.4 \%$ for silts, clays and sand, respectively. Around the stream inlet (site $1 \mathrm{G}$ ), sediments contained a quite proportion of sand $(0.72 \%)$, which is a result of the river organic matter deposition. This hypothesis can be confirmed by the correlation between other physico-chemical parameters including organic matter (OM), silts and clays in this site (Haller et al. 2009a, b). Past studies have reported that distribution of sediment OM and grain size have displayed large variations on these parameters in freshwaters, lakes, rivers and reservoir (Haller et al. 2009a; Poté et al. 2008). According to their results, the organic matter in noncontaminated freshwater sediments varied from 0.2 to $6.0 \%$. The sediment of Lake Ma Vallée could therefore be considered as rich in organic matter content, but not polluted by organic matter. For, e.g. sediments contaminated by the municipal WWTP effluent waters, OM can reach the values of $30 \%$ (Poté et al. 2008). The high organic matter in the sediment of the Lake Ma Vallée can also be explained by the presence of both the agricultural crops in watershed and the dense tropical forest surrounding the lake.

\section{Bacteria levels in water column}

The bacterial concentration in the water column is presented in Table 1. In general, the FIB concentration in the water column is low. The maximum values were

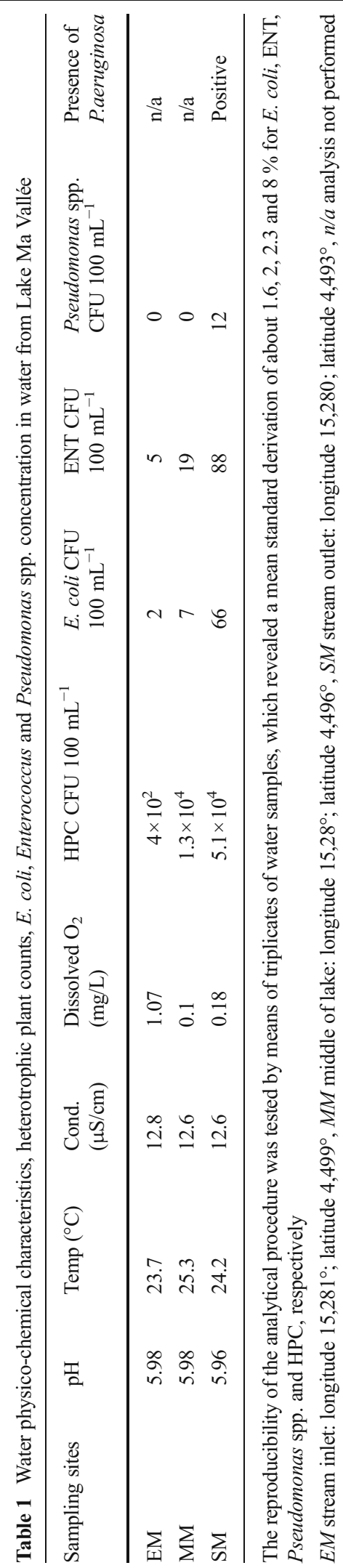


observed in the water samples from the middle of the bay (site MM) and stream outlet of the lake (site SM). For the site SM, values of E. coli and ENT were 66 and $88 \mathrm{CFU} 100 \mathrm{~mL}^{-1}$, respectively. The same tendency was observed for HPC and Pseudomonas values. In the SM site, the maximum obtained values were $5.1 \times$ $10^{4}$ and $12 \mathrm{CFU} 100 \mathrm{~mL}^{-1}$ for HPC and Pseudomonas spp., respectively. This finding illustrates the homogeneous distribution of bacteria in the water column of the lake.

According to the European Directive 2006/7/CE concerning the management of bathing water quality, recreational waters are to be classified as poor, if concentrations of $E$. coli exceed $900 \mathrm{CFU} 100 \mathrm{~mL}^{-1}$ and concentrations of ENT exceed $330 \mathrm{CFU} 100 \mathrm{~mL}^{-1}$, based upon a 90-percentile evaluation. The concentrations of FIB obtained in the water column of the Lake Ma Vallée are under the values requirement for recreational/bathing waters. Thus, the Lake Ma Vallée can be considered as moderately contaminated by faecal indicator bacteria and cannot present important human risk. However, even if FIB concentrations in the water samples are low, their presence suggests that pathogenic bacteria of intestinal origin may also be present (Haller et al. 2009a). In this study, the presence of opportunist pathogens, $P$. aeruginosa, was detected in water and this identification reveals that there are more possible chances for the survival of pathogens in the Lake Ma Vallée.

In the vicinity of Lake Ma Vallée, there is no permanent source of pollution input, such as sewage treatment plant or a permanent urban landfill. The pollution of the lake can be explained by several aspects including domestic waste by the tourists, human visitors or wild animals; runoff of wastewater from septic tank and watershed of the lake; or as a result of contamination by human visitors or neighbouring animals. The water sampling took place in June, during dry/stratified period (no rainfall recorded). According to the sampling season, the sunlight (presence of UV radiation) can activate the decay of FIB in the water column (Hughes 2003; Sinton et al. 1999). Additionally, other factors such as the presence of protozoans and bacteriophages and competing autochthonous bacteria can cause considerable inactivation of FIB in the water column (Davies and Bavor 2000; Poté et al. 2009a; Chandran et al. 2011). Thus, increased temperatures, biological activity and potential presence of predation by bacterivores organisms, as well as intense UV radiation, further can

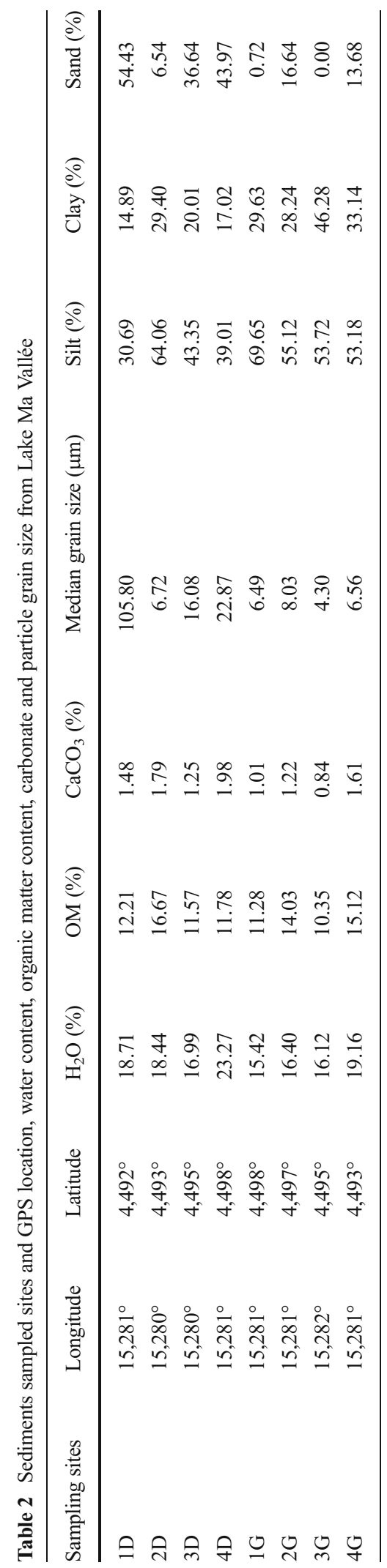


Table 3 Heterotrophic plant count, faecal indicator bacteria (E. coli and Enterococcus) and Pseudomonas spp. distribution in sediments of Lake Ma Vallée

\begin{tabular}{llllll}
\hline Sampling sites & HPC CFU $100 \mathrm{~g}^{-1}$ & E. coli CFU $100 \mathrm{~g}^{-1}$ & ENT CFU $100 \mathrm{~g}^{-1}$ & $\begin{array}{l}\text { Pseudomonas spp. } \\
\text { CFU 100 g }\end{array}$ & $\begin{array}{l}\text { Presence of } \\
\text { P. aeruginosa }\end{array}$ \\
\hline $1 \mathrm{D}$ & $2.84 \times 10^{8}$ & $2.08 \times 10^{3}$ & $9.99 \times 10^{2}$ & $5.64 \times 10^{2}$ & Positive \\
2D & $3.60 \times 10^{8}$ & $6.58 \times 10^{2}$ & $9.87 \times 10^{2}$ & $9.87 \times 10^{2}$ & Negative \\
3D & $1.50 \times 10^{8}$ & $1.7 \times 10^{3}$ & $1.59 \times 10^{3}$ & $32.70 \times 10^{2}$ & Positive \\
$4 \mathrm{D}$ & $3.57 \times 10^{8}$ & $2.75 \times 10^{3}$ & $1.37 \times 10^{3}$ & $30.50 \times 10^{2}$ & Negative \\
$1 \mathrm{G}$ & $2.83 \times 10^{8}$ & $1.02 \times 10^{3}$ & $6.35 \times 10^{3}$ & $21.40 \times 10^{2}$ & Positive \\
$2 \mathrm{G}$ & $3.79 \times 10^{8}$ & $1.19 \times 10^{3}$ & $1.82 \times 10^{3}$ & $31.70 \times 10^{2}$ & Positive \\
$3 \mathrm{G}$ & $0.87 \times 10^{8}$ & $1.38 \times 10^{3}$ & $2.37 \times 10^{3}$ & $14.10 \times 10^{2}$ & Negative \\
$4 \mathrm{G}$ & $1.81 \times 10^{8}$ & $2.65 \times 10^{3}$ & $1.81 \times 10^{3}$ & $9.28 \times 10^{2}$ & Positive \\
\hline
\end{tabular}

The reproducibility of the whole analytical procedure was tested by means of triplicates of selected sediment samples. The bacterial analysis in both water and sediment samples revealed a mean variation coefficient of 3, 7, 2 and $22 \%$ for E. coli, ENT, Pseudomonas spp. and HPC, respectively

contribute to the reduction of FIB levels in the water column of Lake Ma Vallée.

FIB, HPC and Pseudomonas spp. in surface sediments

The FIB, HPC and Pseudomonas spp. distribution in surface sediments of the bay is presented in Table 3. It shows the higher observed concentrations of bacteria in the surface sediments across the whole bay with an emphasis along the beaches. The concentrations of bacteria in all analysed sediments were observed with significant variations within the analysed samples. The FIB concentration values ranged from $6.6 \times 10^{2}$ to $2.7 \times 10^{3}$ and $9.9 \times 10^{2}$ to $6.3 \times 10^{3} \mathrm{CFU} \mathrm{g}^{-1}$, for E. coli and ENT, respectively. The HPC concentration was in order of $10^{8}$ CFU $100 \mathrm{~g}^{-1}$ for all sampling sites. The concentration of Pseudomonas spp. ranged from $5.6 \times 10^{2}$ to $3.27 \times 10^{3}$ CFU $100 \mathrm{~g}^{-1}$. PCR analysis with specific primers for the general confirmation on the isolated bacterial colonies demonstrated that 92,100 and $98 \%$ of the isolated bacteria were E. coli, ENT and Pseudomonas spp., respectively. All isolates confirmed as Pseudomonas spp. were further studied for the presence of pathogen $P$. aeruginos $a$, and the results revealed their presence in both water and sediment isolated colonies.

In the aquatic environment, sediment may constitute a reservoir of different pollutants including toxic metals and microorganisms. Some studies have assessed the presence of bacterial indicators in the sediments and the water column (Anderson et al. 2005; Davis et al. 2005). The influence of environmental conditions on the persistence and accumulation of microorganisms in sediment is higher when compared with the water column, with a potential risk of pollution for coastal recreational water have been demonstrated (LaLiberte and Grimes 1982; Davies et al. 1995; Evanson and Ambrose 2006). Our recent studies demonstrated that the contrasting freshwater sediments can accumulate great levels of FIB than in overlying water (Haller et al. 2009a, b; Poté et al. 2009a, b, 2012; Thevenon et al. 2012). Other studies demonstrated that FIB can survive longer in sediments than in the water column since sediments provide favourable nutrient conditions (Gerba and McLeod 1976; Laliberte and Grimes 1982), protection from sunlight inactivation (Sinton et al. 1999) and protozoan grazing (Davies and Bavor 2000). The results of this study demonstrate clearly that the sediment of a tropical lake-reservoir may contain FIB (including E. coli and ENT) and Pseudomonas spp. at the levels of 100 to 1,000 times higher than that in the water column. Possible resuspension of FIB and pathogens from the sediments to the water column due to recreational activities or natural turbulence may contribute to potential human health risk (An et al 2002; Craig et al. 2004).

In the river-reservoir Lake Ma Vallée, the concentrations of FIB, HPC and Pseudomonas spp. are significantly higher in sediments than in the water column. The risks associated with swimming in microbiologically polluted lakes or rivers during recreational activities are usually not life threatening but could take a substantial toll in children and immune-compromised 
Table 4 Spearman rank order correlation

\begin{tabular}{|c|c|c|c|c|c|c|}
\hline & ENT & $P s$ & $\mathrm{H}_{2} \mathrm{O}$ & $\mathrm{OM}$ & $\mathrm{CaCO}_{3}$ & Median grain size \\
\hline E. coli & -0.19 & -0.0952 & 0.452 & 0.762 & 0.333 & 0.286 \\
\hline ENT & & 0.31 & 0.357 & -0.167 & 0.262 & 0.119 \\
\hline Ps & & & -0.357 & 0.0238 & -0.143 & -0.357 \\
\hline $\mathrm{H}_{2} \mathrm{O}(\%)$ & & & & 0.548 & 0.905 & 0.619 \\
\hline OM (\%) & & & & & 0.667 & 0.286 \\
\hline $\mathrm{CaCO}_{3}(\%)$ & & & & & & 0.571 \\
\hline
\end{tabular}

Variables with correlation coefficients of $P$ values below 0.050 are highlighted in italic

Ps Pseudomonas species

individuals (Clark et al. 2003). Because there are no health standards for beach sediments, it is difficult to assess whether the FIB and Pseudomonas spp. levels measured in sediments of Lake Ma Vallée can pose a health risk. But some studies examined whether the bacteria originating (resuspending) from amount of sediment would exceed health standards for water column (Lee et al. 2006; Haller et al. 2009a, b).

Spearman rank order correlation

The Spearman rank order correlation values are presented in Table 4. There is a strong positive correlation (0.762) between the E. coli and OM, which illustrates that increase with $\mathrm{OM}$ in the natural water reservoir could also significantly increases the $E$. coli distribution in the studied samples. The correlation values are also supportive with our previous studies (Haller et al. 2009a, b) which demonstrated that faecal origin bacteria could survive in the sediments for longer time, depending on the availability of organic matter (Table 5). With other parameters analysed, there was no significant values found for the correlation matrix.

\section{Conclusion}

The results of this study indicate that Lake Ma Vallée presents the lowest values of faecal indicator bacteria in the water column, suggesting that there are no local permanent sources of contamination in the area. Thus, the Lake can be considered as moderately contaminated by FIB bacteria. On the other hand, the accumulation of FIB and Pseudomonas spp. in the sediments of the lake

Table 5 Primers used in the study and their annealing temperature

\begin{tabular}{|c|c|c|c|c|c|}
\hline Target & Primers & Sequence $\left(5^{\prime}\right.$ to $\left.3^{\prime}\right)$ & Annealing Temp $\left({ }^{\circ} \mathrm{C}\right)$ & PCR product (bp) & Reference \\
\hline General E. coli & $\begin{array}{l}\text { ECA75F } \\
\text { ECA619R }\end{array}$ & $\begin{array}{l}\text { GGAAGAAGCTTGCTTC } \\
\text { TTTGCTGAC } \\
\text { AGCCCGGGGATTTCAC } \\
\text { ATCTGACTTA }\end{array}$ & 60 & 544 & Sabat et al. (2000) \\
\hline General Enterococci & $\begin{array}{l}\text { Ent1 } \\
\text { Ent2 }\end{array}$ & $\begin{array}{l}\text { TACTGACAAACCATT } \\
\text { CATGATG } \\
\text { AACTTCGTCACCAACGC } \\
\text { GAAC }\end{array}$ & 55 & 112 & $\begin{array}{l}\text { Ke et al. (1999) and } \\
\text { Morrison et al. (2008) }\end{array}$ \\
\hline $\begin{array}{l}\text { Pseudomonas } \\
\text { species }\end{array}$ & $\begin{array}{l}\text { PA-GS-F } \\
\text { PA-GS-R }\end{array}$ & $\begin{array}{l}\text { GACGGGTGAGTAATGC } \\
\text { CTA } \\
\text { CACTGGTGTTCCTTC } \\
\text { CTATA }\end{array}$ & 54 & 618 & Spilker et al. (2004) \\
\hline P. aeruginosa & $\begin{array}{l}\text { VIC } 1 \\
\text { VIC } 2\end{array}$ & $\begin{array}{l}\text { TTCCCTCGCAGAGAA } \\
\text { AACATC } \\
\text { CCTGGTTGATCAGGT } \\
\text { CGATCT }\end{array}$ & 60 & 520 & Da Silva Filho et al. (1999) \\
\hline
\end{tabular}


was observed. This may impact on the potential risks of human infections either by direct uptake or contamination during recreational activities.

To our knowledge, this is the first study to be performed on the assessment of microbial quality in the water column and sediments of Lake Ma Vallée. Under tropical condition, the low concentration of FIB and Pseudomonas spp. in the water column cannot guarantee the sanitary state of the quality of water. Thus, supplementary analyses of both water and sediment, especially on the determination of protozoa and other virus, are needed to assess the microbial quality of water under tropical conditions.

Acknowledgments We are grateful to the financial sources: the Swiss National Science Foundation (grant no. 31003A_150163/1) and Forel Institute, University of Geneva. This research presents the results of tripartite collaboration between University of Geneva (Forel Institute), University of Kinshasa and Pedagogic National University of Congo (Democratic Republic of Congo) and Jamal Mohamed College (Affiliated to Bharathidasan University), Tiruchirappalli, Tamil Nadu, India. Naresh Devarajan is a Ph.D. scholar supported by a Swiss Government Scholarships for Foreign Scholars.

\section{References}

An, Y., Kampbell, D. H., \& Breidenbach, G. P. (2002). Escherichia coli and total coliforms in water and sediments at lake marinas. Environmental Pollution, 120, 771-778.

Anderson, L. K., Whitlock, E. K., \& Harwood, J. V. (2005). Persistence and differential of faecal indicator bacteria in subtropical water and sediment. Applied and Environmental Microbiology, 71, 3041-3048.

APHA, AWWA, \& WEF. (2005). Standard methods for the examination of water and wastewater (21st ed.). Washington, D.C: APHA, AWWA, \& WEF. 1368 pp.

Balkwill, D. L., \& Ghiorse, W. C. (1985). Characterization of subsurface bacteria associated with two shallow aquifers in Oklahoma. Applied and Environmental Microbiology, 50, 580-588.

Burton, G., Gunnison, D., \& Lanza, G. (1987). Survival of pathogenic bacteria in various freshwater sediments. Applied and Environmental Microbiology, 53, 633-638.

Chandran, A., Varghese, S., Kandeler, E., Thomas, A., Hatha, M., \& Mazumder, A. (2011). An assessment of potential public health risk associated with the extended survival of indicator and pathogenic bacteria in freshwater lake sediments. International Journal of Hygiene and Environmental Health, 214, 258-264.

Clark, A., Turner, T., Dorothy, K. P., Goutham, J., Kalavati, C., \& Rajanna, B. (2003). Health hazards due to pollution of water along the coast of Visakhapatnam, east coast of India. Ecotoxicology and Environmental Safety, 56, 390-397.
Crabelli, V. J. (1983). Health effects criteria for recreational waters. Research Triangle Park, EPA, 1983, EPA-600/ 1-80-031.

Craig, D. L., Fallowfield, H. J., \& Cromar, N. J. (2002). Enumeration of faecal coliforms from recreational coastal sites: evaluation of techniques for the separation of bacteria from sediments. Journal of Applied Microbiology, 93, 557565.

Craig, D. L., Fallowfield, H. J., \& Cromar, N. J. (2004). Use of microcosms to determine persistence of Escherichia coli in recreational coastal water and sediment and validation with in situ measurements. Journal of Applied Microbiology, 96, 922-930.

Da Silva Filho, L. V., Levi, J. E., Oda Bento, C. N., da Silva Ramos, S. R., \& Rozov, T. (1999). PCR identification of Pseudomonas aeruginosa and direct detection in clinical samples from cystic fibrosis patients. Journal of Medical Microbiology, 48, 357-361.

Davies, C., \& Bavor, H. (2000). The fate of storm-water associated bacteria in constructed wetland and water pollution control pond systems. Journal of Applied Microbiology, 89, 349360.

Davies, C. M., Long, J. A. H., Donald, M., \& Ashbolt, N. (1995). Survival of fecal microorganisms in marine and freshwater sediments. Applied and Environmental Microbiology, 61, 1888-1896.

Davis, K., Anderson, M. A., \& Yates, M. V. (2005). Distribution of indicator bacteria in Canyon Lake, California. Water Research, 39, 1277-1288.

EU, European Directive 2006/7/CE of the European Parliament and of the Council of 15 February 2006 concerning the management of bathing water quality and repealing Directive 76/160/EEC.

Evanson, M., \& Ambrose, R. F. (2006). Sources and growth dynamics of fecal indicator bacteria in a coastal wetland system and potential impacts to adjacent waters. Water Research, 40, 475-486.

Ferguson, D. M., Moore, D. F., Getrich, M. A., \& Zhowandai, M. H. (2005). Enumeration and speciation of enterococci found in marine and intertidal sediments and coastal water in southern California. Journal of Applied Microbiology, 99, 598608.

Gerba, C., \& McLeod, J. S. (1976). Effect of sediment on the Survival of Escherichia coli in marine water. Applied and Environmental Microbiology, 32, 114-120.

Haile, R. W., White, J. S., Gold, M., Cressey, R., McGee, C., Millikan, R. C., Glasser, A., Harawa, N., Ervin, C., Harmon, P., Harper, J., Dermand, J., Alamillo, J., Barrett, K., Nides, M., \& Wang, G. Y. (1999). The health effects of swimming in ocean water contaminated by storm drain runoff. Epidemiology, 10, 355-363.

Haller, L., Poté, J., Loizeau, J.-L., \& Wildi, W. (2009a). Distribution and survival of faecal indicator bacteria in the sediments of the Bay of Vidy, Lake Geneva, Switzerland. Ecological Indicators, 9, 540-547.

Haller, L., Amedegnato, E., Poté, J., \& Wildi, W. (2009b). Influence of freshwater sediment characteristics on persistence of fecal indicator bacteria. Water, Air, and Soil Pollution, 203, 217-227.

Hughes, K. A. (2003). Influence of seasonal environmental variables on the distribution of presumptive fecal coliforms 
around an Antarctic Research Station. Applied and Environmental Microbiology, 69, 4884-4891.

Kay, D., Jones, F., Wyer, M. D., Fleisher, J. M., Salmon, R. L., Godfree, A. F., Zelenauch-Jacquotte, A., \& Shore, R. (1994). Predicting likelihood of gastroenteritis from sea bathing: results from randomised exposure. The Lancet, 344, 905909.

Ke, D., Picard, F. J., Martineau, F., Ménard, C., Roy, P. H., Ouellette, M., \& Bergeron, M. G. (1999). Development of a PCR assay for rapid detection of enterococci. Journal of Clinical Microbiology, 37, 3497-3503.

LaLiberte, P., \& Grimes, D. J. (1982). Survival of Escherichia coli in lake bottom sediment. Applied and Environmental Microbiology, 43, 623-628.

Lee, C. M., Lin, T. Y., Lin, C., Kohbodi, G. A., Bhatt, A., Lee, R., \& Jay, J. A. (2006). Persistence of fecal indicator bacteria in Santa Monica Bay beach sediments. Water Research, 40, 2593-2602.

Loizeau, J.-L., Arbouillle, D., Santiago, S., \& Vernet, J.-P. (1994). Evaluation of a wide range laser diffraction grain size analyser for use with sediments. Sedimentology, 41, 353361.

Montgomery, M. A., \& Elimelech, M. (2007). Water and sanitation in developing countries: including health in the equation. Environmental Science and Technology, 41, 17-24.

Morrison, C., Bachoon, D., \& Gates, K. (2008). Quantification of enterococci and Bifidobacteria in Georgia estuaries using conventional and molecular methods. Water Research, 42, 4001-4009.

Noble, R. T., Moore, D. F., Leecaster, M. K., McGee, C. D., \& Welsberg, S. B. (2003). Comparison of total coliform, fecal coliform, and enterococcus bacterial indicator response for ocean recreational water quality testing. Water Research, 37, $1637-1643$.

Poté, J., Haller, L., Loizeau, J.-L., Garcia Bravo, A., Sastre, V., \& Wildi, W. (2008). Effects of a sewage treatment plant outlet pipe extension on the distribution of contaminants in the sediments of the Bay of Vidy, Lake Geneva, Switzerland. Bioresource Technology, 99, 7122-7131.

Poté, J., Haller, L., Kottelat, R., Sastre, V., Arpagaus, P., \& Wildi, W. (2009a). Persistence and growth of faecal culturable bacterial indicators in water column and sediments of Vidy Bay, Lake Geneva, Switzerland. Journal of Environmental Sciences, 21, 62-69.

Poté, J., Goldscheider, N., Haller, L., Zopfi, J., Khajehnouri, F., \& Wildi, W. (2009b). Origin and spatial-temporal distribution of fecal bacteria in a bay of Lake Geneva, Switzerland. Environmental Monitoring and Assessment, 154, 337-348.

Poté, J., Garcia Bravo, A., Mavingui, P., Ariztegui, D., \& Wildi, W. (2010). Evaluation of quantitative recovery of bacterial cells and DNA from different lake sediments by Nycodenz density gradient centrifugation. Ecological Indicators, 10(2), 234-240.
Poté, J., Thevenon, F., \& Wildi, W. (2012). Les indicateurs de bactéries pathogènes résistantes aux antibiotiques dans les sédiments du Léman. Archive des Sciences, 65, 165-176.

Prüss, A. (1998). Review of epidemiological studies on health effects from exposure to recreational water. International Journal of Epidemiology, 27, 1-9.

Sabat, G., Rose, P., Hickey, W. J., \& Harkin, J. M. (2000). Selective and sensitive method for PCR amplification of Escherichia coli 16S rRNA genes in soil. Applied and Environmental Microbiology, 66, 844-849.

Scott, T. M., Parveen, S., Portier, K. M., Rose, J. B., Tamplin, M. L., Farrah, S. R., Koo, A., \& Lukasik, J. (2003). Geographical variation in ribotype profiles of Escherichia coli isolates from humans, swine, poultry, beef, and dairy cattle in Florida. Applied and Environmental Microbiology, 69, 1089-1092.

Sinton, L., Finlay, R., \& Lynch, P. (1999). Sunlight inactivation of fecal bacteriophages and bacteria in sewage-polluted seawater. Applied and Environmental Microbiology, 66, 230-237.

Spilker, T., Coenye, T., Vandamme, P., \& LiPuma, J. J. (2004). PCR-based assay for differentiation of Pseudomonas aeruginosa from other Pseudomonas species recovered from cystic fibrosis patients. Journal of Clinical Microbiology, 42(5), 2074-2079.

Thevenon, F., Regier, N., Benagli, C., Tonolla, M., Adatte, T., Wildi, W., \& Poté, J. (2012). Characterization of faecal indicator bacteria in sediments cores from the largest freshwater lake of Western Europe (Lake Geneva, Switzerland). Ecotoxicology and Environmental Safety, 78, 50-56.

Thevenon, F., Adatte, T., Wildi, W., \& Poté, J. (2013). A highresolution historical sediment record of nutrients, trace elements and organochlorines (DDT and PCB) deposition in a drinking water reservoir (Lake Brêt, Switzerland) points at local and regional pollutant sources. Chemosphere, 2013, 2444-2452.

U.S. Environmental Protection Agency. (2000). Improved enumeration methods for the recreational water quality indicators: enterococci and Escherichia coli EPA-821/R-97/004. Washington, D.C.: U.S. Environmental Protection Agency.

Varga, L. (2001). Bacteriological quality of bottled natural mineral waters commercialized in Hungary. Food Control, 2, 591595.

Walsh, S. P., Metzger, D. A., \& Higuchi, R. (1991). Chelex 100 as a medium for simple extraction of DNA for PCR-based typing from forensic material. Biotechniques, 10(4), 506513.

WHO. (2004). Guidelines for drinking-water quality, recommendations (3rd ed., Vol. 1). Geneva: World Health Organization. 515 pp.

Yang, J. L., Wang, M. S., Cheng, A. C., Pan, K. C., Li, C. F., \& Deng, S. X. (2008). A simple and rapid method for extracting bacterial DNA from intestinal microflora for ERIC-PCR detection. World Journal of Gastroenterology, 14, 28722876 . 